\title{
HUBUNGAN DUKUNGAN PASANGAN DENGAN PEMBERIAN ASI EKSKLUSIF DI DESA TANDAN SARI KECAMATAN TAPUNG HILIR KABUPATEN KAMPAR PROVINSI RIAU
}

\author{
Andalia Roza ${ }^{(1)}$ Rizky Dwi Lestari ${ }^{(2)}$, Nike Puspita alwi ${ }^{(3)}$ \\ ${ }^{1}$ Fakultas Kedokteran dan Ilmu Kesehatan Universitas Abdurrab \\ andalia.roza@univrab.ac.id \\ ${ }^{2}$ Fakultas Kedokteran dan Ilmu Kesehatan Universitas Abdurrab \\ rizki.dwilestari@univrab.ac.id \\ ${ }^{3}$ Fakultas Kedokteran dan Ilmu Kesehatan Universitas Abdurrab \\ nike.puspitaalwi@univrab.ac.id
}

\begin{abstract}
Couple's support having a role in the success or failure of a mother to breastfeed her baby. The greater the support obtained to breastfeed, the greater the ability to survive. This research aimed to know the couple's support with exclusive breastfeeding in Tandan sari Village Tapung hilir Sub-district Kampar Regency in Riau Province. The design of this research used a descriptive correlation study with a cross sectional approach. The population in this research were mother's who had children aged $6-24$ month's. the sample in this research amounted to 65 respondents. Data collection was carried out in march 2020 with the use of a questionnaire. Chi-square test data analysis found a significant relationship between support couple's with a exclusive breastfeeding, with a p-value $=0,017$ meaning $p$-value $<0,05$. Based on the results of the study the researchers suggested that the puskesmas and health workers expand the targets of health promotion related to exclusive breastfeeding involving the husband as the target.
\end{abstract}

Keyword : Couple's support, Exclusive breastfeeding.

\begin{abstract}
ABSTRAK
Dukungan pasangan mempunyai peran dalam sukses atau tidaknya seorang ibu dalam menyusui bayinya. Semakin besar dukungan yang didapatkan untuk menyusui bayinya maka semakin besar kemampuan untuk bertahan dalam menyusui. Penelitian ini mempunyai tujuan untuk mengetahui hubungan dukungan pasangan dengan pemberian ASI eksklusif di Desa Tandan sari Kecamatan Tapung Hilir Kabupaten Kampar Provinsi Riau. Desain penelitian ini menggunakan jenis penelitian Deskriptif korelasi dengan pendekatan cross sectional. Populasi dalam penelitian ini adalah ibu yang memiliki anak usia 6 - 24 bulan. Sampel dalam penelitian ini berjumlah 65 responden. Pengumpulan data dilakukan pada bulan maret 2020 dengan menggunakan kuesioner. Analisis data uji Chi-square didapatkan hubungan yang signifikan antara dukungan pasangan dengan pemberian ASI eksklusif, dengan nilai $\mathrm{p}$-value $=0,017$ artinya $\mathrm{p}$-value $<0,05$. Berdasarkan hasil penelitian tersebut peneliti menyarankan agar puskesmas dan tenaga kesehatan memperluas sasaran promosi kesehatan yang berhubungan dengan pemberian ASI eksklusif yang melibatkan suami sebagai sasaran.
\end{abstract}

Kata kunci : Dukungan Pasangan, pemberian ASI Eksklusif

\section{PENDAHULUAN}

Air susu ibu (ASI) adalah cairan hidup yang terdiri atas $85 \%$ air dengan perpaduan sempurna dari kalori, protein, lemak, dan karbohidrat (laktosa) bukan 
hanya suatu nutrisi untuk bayi, tetapi terdiri atas enzim amylase dan lipase untuk membantu mencerna zat tepung dan lemak imonologi dan antibody lainnya untuk system kekebalan, serta melindungi bayi dari infeksi (gray dan Hills, 2015). Air Susu Ibu (ASI) merupakan sumber gizi yang sangat ideal dengan komposisi yang disesuaikan dengan kebutuhan pertumbuhan bayi selama 6 bulan dan memberikan banyak keuntungan yang berdampak baik pada pertumbuhan fisik yang sempurna (Astutik, 2014). ASI sangat diperlukan untuk pertumbuhan dan perkembangan kecerdasan anak. Menurut penelitian, anak-anak yang tidak diberi ASI menpunyai IQ (Intellectual Quotient) lebih rendah 7-8 poin dibandingkan dengan anakanak yang diberi ASI secara Eksklusif (Yuliarti, 2010).

Data profil kesehatan Indonesia angka kematian bayi tahun tahun 2015 adalah 22,23/1000 kelahiran hidup (Kemenkes, 2017). Menurunkan angka kematian bayi dan balita maksimum 12-25 setiap setiap 1000 kelahiran hidup ditahun 2030 merupakan target ketiga Sustainable Development Goals (SDGs) (Rutgers WPF Indonesia, 2015) kematian bayi sebagian besar karena diare, pneumonia dan mayoritas disebabkan oleh kurang gizi, intervensi tepat untuk menurunkan angka kematian bayi menerapkan pemberian ASI eksklusif (sulistiyono \& Siswantara, 2014). Dalam rangka menurunkan angka kesakitan dan kematian anak, United Nation Childrens Fund (UNICEF) dan World Health Organization (WHO) merekomendasikan sebaiknya anak hanya disusui air susu ibu (ASI) selama paling sedikit enam bulan, setelah itu anak harus di beri makanan padat dan semi padat sebagai makanan tambahan selain ASI (Kementrian Kesehatan RI, 2014). Dapartemen Kesehatan RI (2010) mencatat saat ini jumlah ibu yang memberikan ASI eksklusif kepada bayinya sampai umur enam bulan masih rendah, yaitu kurang dari $12 \%$ dari jumlah ibu melahirkan.

Berdasarkan penelitian yang dilakukan di Amerika Serikat di dapatkan bahwa bayi yang diberikan ASI eksklusif selama enam bulan memiliki resiko $72 \%$ lebih rendah mengalami infeksi saluran pernafasan, resiko $50 \%$ lebih rendah mengalami infeksi saluran otitis media, dan resiko $30 \%$ lebih rendah mengalami diabetes. Selain itu ASI juga dapat menurunkan sudden infant death syndrome (SIDS) sebesar 36\% (American Academy of Pediatrics, 2012).

Cakupan ASI eksklusif berdasarkan data WHO tahun 2016 pada bayi usia 0- 6 bulan diseluruh dunia adalah sebesar $40 \%$ belum mencapai target cakupan ASI eksklusif didunia sebesar 50\%, sedangkan cakupan pemberian ASI eksklusif di ASIA adalah sebesar 47\% pada tahun 2013 (WHO, 2013). Cakupan ASI Eksklusif berdasarkan data profil kesehatan Indonesia tahun 2018 di Indonesia tahun 2018 sebesar $68,74 \%$ angka tersebut sudah melampaui target Renstra tahun 2018 yaitu 47\%. dan cakupan ASI Eksklusif di Riau sebesar $35,01 \%$ (Direktorat Jendral Kesehatan Masyarakat, Kemenkes RI, 2019). Berdasarkan data Riskesdas 2018 cakupan ASI Eksklusif di Indonesia sebesar $45.0 \%$ dan cakupan ASI Eksklusif Di Riau sebesar $55.0 \%$ (Riskesdas, 2018).

Cakupan ASI eksklusif yang rendah disebabkan oleh beberapa faktor antara lain faktor predisposing (faktor pemudah) seperti pendidikan, pengetahuan, nilai- nilai atau adat budaya, ada juga faktor enabling (faktor-faktor pendukung) seperti pendapatan keluarga, ketersediaan waktu, kesehatan ibu, dan faktor reinforcing (faktor pendorong) seperti dukungan keluarga dan dukungan petugas kesehatan (Haryono \& Sulis, 2014).

Agar tercapainya pemberian ASI 
eksklusif selama enam bulan diperlukan motivasi keluarga untuk mendukung keberhasilan menyusui. Keluarga memberikan kontribusi yang besar terhadap keinginan ibu untuk menyusui bayinya. Keberhasilan dalam pemberian ASI eksklusif dibutuhkan juga motivasi yang diberikan oleh tenaga kesehatan adalah dengan memberikan pendidikan menyusui melalui penyuluhan ataupun konseling yang diberikan sejak masa antenatal (Harnilawati, 2013). Menurut Haryono \& Setianingsih, dukungan ini didapat oleh ibu dari dua pihak, yaitu keluarga dan tenaga kesehatan. Tetapi pengaruh dukungan yang paling besar adalah dukungan keluarga terlebih dari suami. Hal ini dikarenakan suami merupakan keluarga inti dan orang yang paling dekat dengan ibu. Namun pada kenyataannya, dukungan suami dalam praktek pemberian ASI masih minim, salah satunya karena secara kultural ada pembagian peran, dimana suami berperan sebagai pencari nafkah dan urusan rumah tangga semuanya diuurusi oleh istri (Malau, 2010).

Pada dasarnya dukungan suami sangat berarti dalam menghadapi tekanan ibu dalam menjalani proses menyusui. Dukungan suami dan keluarga membuat ibu tenang sehingga memperlancar produksi ASI. Jadi agar proses menyusui lancar, diperlukan breastfeeding father yaitu ayah membantu ibu agar bisa menyusui dengan nyaman sehingga ASI yang dihasilkan maksimal (Nur Khasanah, 2011). Penelitian sebelumnya mengenai dukungan suami yang dilakukan oleh Fili (2017) mahasiswa Universitas Ibn Khaldun Bogor, yang berjudul "Hubungan Pengetahuan, Sikap, dan Dukungan Suami Terhadap Pemberian ASI Eksklusif Di Desa Pabuaran Kecamatan Gunung Sindur Kabupaten Bogor Tahun 2017”. Hasil penelitian menunjukkan terdapat hubungan yang bermakna antara dukungan suami dengan pemberian ASI eksklusif. Suami yang memiliki dukungan baik terhadap pemberian ASI eksklusif akan memberikan dampak yang baik pula bagi ibu dalam pemberian ASI eksklusif. Beberapa penelitin menyatakan dukungan keluarga mempunyai hubungan dengan pemberian ASI eksklusif. Penelitian Abidjulu, dkk 2015 diperoleh bahwa terdapat hubungan yang signifikan antara dukungan suami dengan kemauan ibu memberikan ASI eksklusif.

Berdasarkan hasil survey awal yang dilakukan oleh peneliiti pada tanggal 11 November 2019 di Puskesmas Tapung Hilir II terdapat bahwa cakupan pemberian ASI eksklusif pada tahun 2018 sebesar 26,14\% dan tahun 2019 cakupan pemberian ASI eksklusif sebesar 39,77\% meskipun capain ini terus meningkat persentase pemberian ASI eksklusif pada bayi belum mencapai target $80 \%$. Berdasarkan wawancara dengan 10 orang ibu menyusui didapatkan data bahwa sebanyak 4 ibu menyusui menyatakan bahwa bayinya diberikan ASI saja tanpa adanya pemberian makanan lainnya sejak bayi lahir sampai bayi berumur 6 bulan, sebanyak 3 ibu menyusui menyatakan bahwa bayinya sudah diberikan makanan tambahan selain ASI disebabkan karena ibu bekerja dan sebanyak 3 orang ibu menyusui mengatakan bahwa ASI saja tidak cukup untuk bayinya dan keluarga tidak mendorong ibu untuk memberikan ASI eksklusif pada bayinya. Adapun alasan peneliti melakukan penelitian tersebut bertujuan untuk mengetahui hubungan dukungan pasangan dengan pemberian ASI eksklusif di Desa Tandan Sari Kecamatan tapung Hilir Kabupaten Kampar Provinsi Riau.

Sebanyak 4 ibu menyusui menyatakan bahwa bayinya diberikan ASI saja tanpa adanya pemberian makanan lainnya sejak bayi lahir sampai bayi 
berumur 6 bulan, sebanyak 3 ibu menyusui menyatakan bahwa bayinya sudah diberikan makanan tambahan selain ASI disebabkan karena ibu bekerja dan sebanyak 3 orang ibu menyusui mengatakan bahwa ASI saja tidak cukup untuk bayinya dan keluarga tidak mendorong ibu untuk memberikan ASI eksklusif pada bayinya. Adapun alasan peneliti melakukan penelitian tersebut bertujuan untuk mengetahui hubungan dukungan pasangan dengan pemberian ASI eksklusif di Desa Tandan Sari Kecamatan tapung Hilir Kabupaten Kampar Provinsi Riau.

\section{METODE PENELITIAN}

Dalam penelitian ini peneliti menggunakan jenis penelitian yang bersifat deskriptif korelasi dengan desain penelitian cross sectional. Penelitian ini telah dilakukan di Desa Tandan Sari Kecamatan Tapung Hilir Kabupaten Kampar Provinsi Riau tahun 2020. Waktu pengumpulan data pada bulan Maret- April 2020. Pada penelitian ini populasinya adalah ibu yang memiliki anak berusia 6-24 bulan yang berjumlah 65 orang di Desa Tandan Sari Kecamatan Tapung Hilir Kabupaten Kampar Provinsi Riau tahun 2020. Teknik pengambilan sampel dengan teknik total sampling sehingga semua populasi diambil sebagai sampel.

Instrumen penelitian adalah alat untuk melakukan pengumpulan data, peneliti menggunakan kuisioner yang tervalidasi dibuat sesederhana mungkin agar mudah dipahami. Ada empat tahapan dalam pengelohan data, yaitu : Editing (Pengeditan Data), Coding (Pengkodean Data), Entry (Pemindahan Data Komputer), Cleaning (Pembersihan Data). Analisis data dilakukan dengan alat bantu pragram komputerisasi SPSS yang melihat analisis Univariat dan Bivariat.

\section{HASIL DAN PEMBAHASAN \\ Hasil Penelitian}

Penelitian ini dilakukan pada tanggal 0710 Maret 2020. Sampel dalam penelitian ini sebanyak 65 responden yang memiliki anak usia 0-2 tahun. Karakteristik responden pada penelitian ini berdasarkan Nama (inisial), umur, pendidikan, pekerjaan, dan usia bayi. Deskripsi karakteristik responden disajikan dalam kategori sebagai berikut :

Tabel 1

Karakteristik Responden

Berdasarkan Usia

\begin{tabular}{cccc}
\hline No & Usia & $\begin{array}{c}\text { Fr } \\
\text { ek } \\
\text { ue } \\
\text { nsi }\end{array}$ & $\begin{array}{c}\text { Persentase } \\
(\mathbf{\%})\end{array}$ \\
& & 7 & \\
\hline 1 & $20-23$ tahun & 14 & $21 \%$ \\
2 & $24-27$ tahun & 18 & $27 \%$ \\
3 & $28-31$ tahun & 9 & $14 \%$ \\
4 & 32-35 tahun & 8 & $13 \%$ \\
5 & $36-39$ tahun & 8 & $13 \%$ \\
6 & $40-43$ tahun & 1 & $1 \%$ \\
7 & $44-47$ tahun & $\mathbf{6 5}$ & $\mathbf{1 0 0}$ \\
\hline & Jumlah & &
\end{tabular}

Tabel 2

Karakteristik Responden

Berdasarkan Pendidikan

\begin{tabular}{cccc}
\hline No & Pendidikan & $\begin{array}{c}\text { Fre } \\
\text { kue } \\
\text { nsi }\end{array}$ & $\begin{array}{c}\text { Persentase } \\
(\mathbf{\%})\end{array}$ \\
\hline 1 & SD & 3 & $5 \%$ \\
2 & SMP & 11 & $17 \%$ \\
3 & SMA & 30 & $46 \%$ \\
4 & DIII & 10 & $15 \%$ \\
5 & S1 & 11 & $17 \%$ \\
\hline & Jumlah & $\mathbf{6 5}$ & $\mathbf{1 0 0}$ \\
\hline
\end{tabular}

Tabel 3

Karakteristik Responden

Berdasarkan Pekerjaan

\begin{tabular}{cccc}
\hline No & Pekerjaan & $\begin{array}{c}\text { Fre } \\
\text { kue }\end{array}$ & $\begin{array}{c}\text { Persentase } \\
(\%)\end{array}$ \\
\hline
\end{tabular}




\begin{tabular}{cccc}
\hline \multicolumn{3}{c}{ nsi } \\
\hline 1 & Guru & 9 & $14 \%$ \\
2 & IRT & 39 & $60 \%$ \\
3 & Pedagang & 9 & $14 \%$ \\
4 & Karyawan & 6 & $9 \%$ \\
5 & Wiraswast & 2 & $3 \%$ \\
& a & & \\
\hline & Jumlah & $\mathbf{6 5}$ & $\mathbf{1 0 0}$ \\
\hline
\end{tabular}

Tabel 4

Karakteristik Responden

Tabel 7

Berdasarkan Usia Bayi

\begin{tabular}{cccc}
\hline No & Usia Bayi & $\begin{array}{c}\text { Fre } \\
\text { kue } \\
\text { nsi }\end{array}$ & $\begin{array}{c}\text { Persenta } \\
\text { se } \\
(\boldsymbol{\%})\end{array}$ \\
\hline 1 & 6-10 bulan & 13 & $20 \%$ \\
2 & $11-15$ bulan & 15 & $23 \%$ \\
3 & $16-20$ bulan & 14 & $22 \%$ \\
4 & $21-25$ bulan & 23 & $35 \%$ \\
\hline & Jumlah & $\mathbf{6 5}$ & $\mathbf{1 0 0}$ \\
\hline
\end{tabular}

Tabel 5

Gambaran Dukungan

Pasangan di Desa Tandan Sari

\begin{tabular}{cccc}
\hline No & $\begin{array}{c}\text { Tingkat } \\
\text { Dukungan } \\
\text { Pasangan }\end{array}$ & Frekuensi & $\begin{array}{c}\text { Persentase } \\
(\%)\end{array}$ \\
\hline 1 & Mendukung & 39 & $60 \%$ \\
2 & Kurang & 26 & $40 \%$ \\
& Mendungkung & & \\
\hline & Jumlah & $\mathbf{6 5}$ & $\mathbf{1 0 0}$ \\
\hline
\end{tabular}

Tabel 6

Gambaran Pemberian ASI

Eksklusif

\begin{tabular}{cccc}
\hline No & $\begin{array}{c}\text { Tingkat } \\
\text { Pemberian } \\
\text { ASI } \\
\text { Eksklusif }\end{array}$ & $\begin{array}{c}\text { Fre } \\
\text { kue } \\
\text { nsi }\end{array}$ & $\begin{array}{c}\text { Pers } \\
\text { enta } \\
\text { se } \\
(\boldsymbol{\%})\end{array}$ \\
\hline 1 & Ya & 32 & $47 \%$ \\
2 & Tidak & 33 & $53 \%$ \\
\hline & Jumlah & $\mathbf{6 5}$ & $\mathbf{1 0 0}$ \\
\hline
\end{tabular}

Pembahasan

\section{Dukungan Pasangan}

Berdasarkan hasil penelitian, didapatkan distribusi berdasarkan dukungan pasangan yang terbanyak adalah responden yang memiliki pasangan yang mendukung dengan jumlah 39 responden $(60 \%)$ dan pasangan yang tidak mendukung sebanyak 24 responden (40\%). Dukungan pasangan merupakan dukungan yang diberikan suami terhadap istri, suatu bentuk dukungan dimana suami dapat memberikan bantuan secara psikologis baik berupa motivasi, perhatian dan penerimaan diri (Jacinta, 2010).

Sejalan dengan penelitian yang dilakukan oleh Bakri (2018) menunjukan 
bahwa dari 83 responden ternyata 49 responden $(59 \%)$ mendapatkan dukungan pasangan yang baik dan 34 responden (41\%) lainnya tidak memiliki dukungan pasangan yang baik.

Dari penjabaran di atas, menurut asumsi peneliti bahwa pada hasil penelitian ini dukungan pasangan di Desa Tandan Sari sudah memiliki dukungan pasangan yang baik. Pasangan mendukung pemberian ASI eksklusif dipengaruhi oleh faktor internal dan eksternal. Karena tidak hanya dukungan materil aja, dukungan secara moril.

\section{Pemberian ASI Eksklusif}

Hasil penelitian yang didapatkan berdasarkan pemberian ASI eksklusif yang terbanyak adalah responden yang memberikan ASI eksklusif dengan jumlah 33 responden $(50 \%)$ dan yang tidak memberikan ASI eksklusif sebanyak 32 responden (50\%). Pemberian ASI eksklusif merupakan makanan terbaik untuk bayi yang mengandung sel darah putih, protein dan zat kekebalan yang cocok untuk bayi (WHO, 2013).

Hasil yang didapatkan sejalan dengan hasil penelitian Bakri (2018) menunjukan bahwa dari 83 responden, 54 responden $(65,1 \%)$ sudah memberikan ASI eksklusif pada bayinya dan 29 responden $(34,9 \%)$ diantaranya tidak memberikan ASI eksklusif pada bayi mereka.

Dengan demikian menurut asumsi peneliti bahwa pada hasil penelitian ini di Desa Tandan Sari para ibu sudah banyak yang memberikan ASI eksklusif kepada bayi mereka. Karena ibu yakin bahwa ASI eksklusif adalah makanan yang terbaik atau paling tepat untuk bayi, karena ASI berperan penting dalam tubuh bayi.

\section{Hubungan Dukungan Pasangan dengan Pemberian ASI Eksklusif}

Hasil penelitian mengenai hubungan dukungan pasangan dengan pemberian ASI eksklusif di Desa Tandan Sari menunjukkan bahwa responden yang mendapatkan dukungan pasangan yang mendukung dan memberikan ASI eksklusif sebanyak 33 orang atau sekitar $53 \%$, sedangkan responden yang mendapatkan dukungan pasangan yang kurang mendukung dan memberikan ASI eksklusif sebanyak 32 orang atau sekitar 47\%. Berdasarkan hasil uji statistik didapatkan nilai p-value sebesar 0,017 artinya p-value $<0,05$, maka dapat dikatakan bahwa terdapat ada hubungan antara dukungan pasangan dengan pemberian ASI ekskslusif. Hasil penelitian ini sejalan dengan penelitian Setiowati (2011) yang menyatakan bahwa terdapat hubungan antara dukungan pasangan dengan pemberian ASI eksklusif.

Hasil analisis yang didapatkan terdapat 14 responden (22\%) yang mendapatkan dukungan pasangan, namun tidak memberikan ASI kepada anak. Terdapat juga 18 responden (28\%) tidak mendapat dukungan pasangan, tetapi tetap memberikan ASI kepada anak. Fahma (2011) mengungkapkan hal tersebut terjadi dikarenakan meskipun suami mendukung atau tidak mendukung untuk tetap memberikan ASI, namun kemauan ibu bukan hanya didukung oleh dukungan yang diberikan oleh suami tetapi kemauan ibu sendiri dipengaruhi beberapa faktor diantaranya keadaan fisik ibu yang tidak mendukung, kurangnya produksi ASI, cara menyusui ibu yang salah, dan lingkungan di sekitar ibu.

Peran keluarga dalam mendukung ibu berpengaruh terhadap keberhasilan ASI eksklusif. Dukungan yang berasal dari keluarga baik suami, ibu, mertua, dan anggota keluarga lainnya yang sudah mempunyai pengalaman menyusui biasanya menjadi dominan terhadap ibu (Prasetyono, 2012). Menurut Simmon (2011) menyatakan bahwa keberhasilan menyusui erat kaitannya dengan dukungan dari orang-orang disekitar ibu seperti 
suami dan orang tua ibu. Peran suami agar sukses dalam proses menyusui, adalah ayah harus berperan aktif dalam pengambilan keputusan, memiliki sikap positif, dan memiliki pengetahuan yang baik tentang manfaat menyusui.

Terdapat beberapa faktor yang dapat memengaruhi ibu tidak ingin memberikan ASI pada anak. Hal tersebut meliputi faktor fisik, batin, psikologis, dukungan tenaga kesehatan, dan dukungan keluarga. Faktor dukungan keluarga terbagi dua yaitu faktor eksternal yang meliputi pekerjaan,

sosial, ekonomi, dukungan suami, dan budaya setempat. Sedangkan dukungan internal meliputi pendidikan, pengetahuan, sikap, dan kondisi psikologis ibu.

Berdasarkan penelitian Sudiharto (2015) menyatakan bahwa dukungan keluarga mempunyai hubungan dengan suksesnya pemberian ASI kepada bayi. Keberhasilan menyusui sangat ditentukan oleh peran ayah karena ayah akan turut menentukan kelancaran reflex pengeluaran ASI yang sangat dipengaruhi oleh keadaan emosi atau perasaan ibu. Ayah dapat berperan aktif dalam membantu ibu dalam memberikan ASI eksklusif dengan memberikan dukungan-dukungan emosional dan bantuan-bantuan lainnya (Roesli, 2013).

Hal tersebut senada dengan penelitian yang dilakukan oleh Paramitha (2012) menyatakan bahwa dukungan suami sangat diperlukan agar pemberian ASI eksklusif bisa tercapai. Penelitian tersebut juga sejalan dengan penelitian yang dilakukan oleh Fili (2017) menyatakan bahwa terdapat hubungan yang bermakna antara dukungan suami dengan pemberian ASI eksklusif.

Hasil penelitian yang dilakukan sejalan dengan penelitian Trisnawati (2012) yang menyatakan bahwa terdapat hubungan yang bermakna antara dukungan keluarga yang baik dengan pemberian ASI eksklusif. Hal ini dikarenakan semakin tinggi pemberian dukungan, maka ibu akan lebih termotivasi, semangat dan yakin selama menyusui. Penelitian Rahman (2015) juga menunjukkan bahwa terdapat hubungan yang signifikan antara dukungan keluarga dengan pemberian ASI eksklusif merupakan suatu respon yang diberikan keluarga dalam mendukung ibu untuk memberikan MP-ASI pada bayi setelah usia enam bulan.

Dengan demikian menurut asumsi peneliti bahwa pada hasil penelitian ini dukungan pasangan erat kaitannya dengan pemberian ASI eksklusif pada bayi di bawah 6 bulan. Hal tersebut dikarenakan dukungan pasangan menjadi hal penting serta pendidikan dan pengetahuan yang dimiliki pasangan juga dapat memengaruhi ibu untuk memberikan ASI eksklusif pada bayi. Pemberian ASI eksklusif didapat bahwa mayoritas ibu memberikan ASI eksklusif kepada anaknya. Serta dukungan suami yang didapat adalah mayoritas ibu mendapatkan dukungan yang baik dari suami ketika memberikan ASI eksklusif.

\section{SIMPULAN}

Dukungan pasangan dengan pemberian ASI eksklusif menunjukkan bahwa responden yang mendapatkan dukungan pasangan yang mendukung dan memberikan ASI eksklusif sebanyak 33 orang atau sekitar 53\%, sedangkan responden yang mendapatkan dukungan pasangan yang kurang mendukung dan memberikan ASI eksklusif sebanyak 32 orang atau sekitar 47\%. Berdasarkan hasil uji statistik didapatkan nilai p-value sebesar 0,017 artinya $\mathrm{p}$-value $<0,05$, maka dapat dikatakan bahwa terdapat ada hubungan antara dukungan pasangan dengan pemberian ASI ekskslusif. 


\section{DAFTAR PUSTAKA}

Abidjulu. (2015). Motivasi Keluarga dan Tenaga Kesehatan Terhadap Ibu Dengan Pemberian ASI Eksklusif Di Kelurahan Baiya Wilayah Kerja Puskesmas Pantoloan. Jurnal Ilmu Kesehatan, 11581167.

Annisa, L. \& Swastiningsih, N. 2015. Dukungan sosial dan DAmpak yang Dirasakan oleh Ibu Menyusui dari SUami. EMPATHY: Jurnal Fakultas Psikologi Ahmad Dahlan, Vol. 3(No.1(No.1).

Ariani, M. 2010. Penguatan Ketahanan Pangan Daerah Untuk Mendukung Ketahanan Pangan Nasional. Pusat Analisis Sosial Ekonomi Dan kebijakan Pertanian. Bogor

Astutik. (2014). motivasi keluarga dan tenaga kesehatan terhadap ibu dengan pemberian ASI eksklusif di kelurahan baiya wilayah kerja puskesmas pantoloan. jurnal ilmu kesehatan, 1158-1167.

Fili. (2017). Hubungan Dukungan Suami Dengan Pemberian ASI Eksklusif Di Wilayah Kerja Puskesmas Sempur Kota Bogor Tahun 2018. PVol.2 No.1, Februari 2019, 27-36.

Gray dan Hills, 2. (2015). motivasi keluarga dan tenaga kesehatan terhadap ibu dengan pemberian asi eksklusif di kelurahan baiya wilayah kerja puskesmas pantoloan. jurnal ilmu kesehatan, 1158-1167.

Harnilawati. (2013). motivasi
Keluarga Dan Tenaga

Kesehatan Terhadap Ibu

Dengan Pemberian ASI Eksklusif Di Kelurahan Baiya Wilayah Kerja Puskesmas Pantoloan. Jurnal Ilmu Kesehatan, 1158-1167.

indonesia, k. k. (2014). motivasi kelurga dan tenaga kesehatan terhadap ibu dengan pemberian asi eksklusif di kelurahan baiya wilayah kerja puskesmas pantoloan. jurnal ilmu kesehatan , 1158-1167.

Ida, 2011. Faktor-faktor yang Berhubungan dengan Pemberian ASI Eksklusif 6 bulan di WIlayah Kerja Puskesmas Muka Kota Depok, Depok: Universitas Indonesia.

Indonesia, R. W. (2015). Hubungan Dukungan Keluarga Dengan Pemberian ASI Eksklusif Pada Ibu Yang Bekerja. JOM FKp, Vol.5 No.2 (JuliDesember) 2018, 336-343

Kemekes. (2017). Hubungan Dukungan Keluarga Dengan Pemberian ASI Eksklusif Pada Ibu Yang Bekerja. JOM FKp, Vol.5 No.2 (Juli-Desember) 2018, 336-343.

Kemenkes. (2017). Hubungan Dukungan Keluarga Dengan Pemberian ASI Eksklusif Pada Ibu Yang Bekerja. JOM FKp, Vol.5 No.2 (Juli-Desember) 2018, 336-343.

Khasanah, N. (2011). Hubungan Dukungan Suami Dengan Pemberian ASI Eksklusif Di Wilayah Kerja Puskesmas Sempur Kota Bogor Tahun 2018. Promotor Jurnal 
mahasiswa

Kesehatan

Masyarakat Vol.2 Nol,

februari 2019, 27-36.

Malau.

(2010).

Hubungan

Dukungan Suami Dengan

Pemberian ASI Eksklusif DI

Wilayah Kerja Puskesmas

Sempur kota Bogor Tahun

2018. Promotor Jurnal

Mahasiswa Kesehatan

Masyarakat Vol.2 No.1,

Februari 2019, 27- 36.

Narfin, 2013.Determinan Pemberian

ASI Eksklusif Daerah

Perumahan Kumuh dan Tidak

Kumuh di Wilayah kerja Puskesmas Jumpadang Baru,

Makasar:

Universitas

Hasanuddin.

Notoarmodjo, S. (2012)Metodologi

Penelitian Kesehatan. Jakarta:

Salemba Medika.

proverawati, A. Rahmawati, E, (2010). Kapita Selekta ASI dan

Menyusui.

Yogyakarta: Nuha Medika.

RI, K. K. (2014). Motivasi keluarga

Dan Teaga Kesehatan

Terhadap ibu Dengan

Pemberian ASI Eksklusif Di

Kelurahan Baiya Wilayah

Kerja Puskesmas Pantoloan.

Jurnal Ilmu Kesehatan, 1158-

1167.

Riau, D. P. (2015). Hubungan dukungan Keluarga Dengan Pemberian ASI Eksklusif Pada Ibu Yang Bekerja. JOM FKp, Vol.5 No.2 (Juli-Desember) 2018, 336-343.

Siswantara, S. \&. (2014). Hubungan Dukungan Keluarga Dengan Pemberian ASI Eksklusif Pada Ibu Yang Bekerja. JOM
FKp,Vol.5 No.2 (JuliDesember) 2018, 336-343.

wattimena \& dkk, September 2015.

Dukungan Suami dengan Keberhasilan Istri untuk Menyusui. Jurnal Ners LENTERA, Vol. 3(No.1), p.10.

WHO. (2013). Hubungan Dukungan Keluarga Dengan Pemberian ASI Eksklusif Pada Ibu Yang Bekerja. JOM FKp, Vol. 5 No. 2 (Juli-Desember) 2018, 336343.

Yuliarti. (2010). Hubungan antara Dukungan Keluarga dengan Pemberian ASI eksklusif pada Bayi di Desa Bebengan Kecamatan Boja Kabupaten Kendal, 1-8 